\title{
PENGARUH KEPEMIMPINAN, BUDAYA ORGANISASI, MOTIVASI TERHADAP KEPUASAN KERJA DAN KINERJA KARYAWAN PADA DINAS PEMERINTAHANAN DESA KABUPATEN LUMAJANG (PEMDES)
}

\author{
Dihan Profita, Surachman, Andarwati \\ Fakultas Ekonomi dan Bisnis, Universitas Brawijaya \\ Email: vita_dihan@yahoo.com
}

\begin{abstract}
The background of this reasearch is that there is effort from enterprises/companies to improve their employees' performance as an objective of an enterprise/company. Performance strongly depends on the awareness of each employee. In order to improve the employees' performance, the enterprise/company is required to maintain the establishment of human resource, by doing, for example, improving the efectiveness and efficiency so that employees feel satisfied, resulting improvement in employees' performance. This research also uses analysis unit consisting of the employees of PEMDES service in Lumajang district with the employees' population of 80 people and uses path analysis method as data analysis technique.

According to the result and discussion, this research's conclusions can be explained as the following: 1) leadership influences work satisfaction; 2) organization's culture influences work satisfaction; 3) motivation influences work satisfaction; 4) leadership influences employees' performance; 5) organization's culture influences employees' performance; 6) motivation influences employees' performance; 7) work satisfaction influences employees' performance, 8) leadership indirectly influences employee's performance through work satisfaction; 9) organization's culture indirectly influences employee's performance through work satisfaction; and 10) motivation indirectly influences employee's performance through work satisfaction at PEMDES service of Lumajang district.
\end{abstract}

Keywords: Leadership, Organization's Culture, Motivation, Work Satisfaction, And Employees' Performance

\begin{abstract}
Abstrak; Penelitian ini dilatar belakangi adanya upaya perusahaan untuk meningkatkan kinerja para karyawan merupakan tujuan yang akan dicapai oleh perusahaan. Kinerja sangat tergantung pada kesadaran dari tiap-tiap karyawan. Untuk meningkatkan kinerja karyawan perusahaan wajib untuk menjaga keberadaan sumber daya manusia salah satu upaya yang dilakukan yaitu dengan meningkatkan efektivitas dan efisiensi sehingga kepuasan kerja karyawan dapat terwujud sehingga dapat meningkatkan kinerja para karyawan. Populasi dalam penelitian ini adalah seluruh karyawan Dinas Pemerintahan Desa (PEMDES) Kabupaten Lumajang yaitu sebanyak 80 karyawan dan menggunakan analisis statistik deskriptif dengan metode analisis jalur (path)

Berdasarkan hasil penelitian dan pembahasan yang telah dilakukan maka simpulan hasil penelitian dapat diuraikan sebagai berikut: 1) Kepemimpinan berpengaruh terhadap kepuasan kerja 2) Budaya organisasi berpengaruh terhadap kepuasan kerja 3) Motivasi berpengaruh terhadap kepuasan kerja 4) Kepemimpinan berpengaruh terhadap kinerja karyawan 5) Budaya organisasi berpengaruh terhadap kinerja karyawan 6) Motivasi berpengaruhterhadap kinerja karyawan 7) Kepuasan kerja berpengaruh pada kinerja karayawan 8) Kepemimpinan mempunyai pengaruh tidak langsung terhadap kinerja karyawan melalui kepuasaan kerja 9) Budaya organisasi mempunyai pengaruh tidak langsung terhadap kinerja karyawan melalui kepuasaan kerja 10) Motivasi mempunyai pengaruh tidak langsung terhadap kinerja karyawan melalui kepuasaan kerja pada Dinas Pemerintahan Desa (PEMDES) Kabupaten Lumajang.
\end{abstract}

Kata Kunci: Kepemimpinan, Budaya Organisasi, Motivasi Kepuasan Kerja dan Kinerja Karyawan 
Sumber daya manusia sebagai salah satu unsur pengendali, merupakan faktor paling penting dan utama didalam segala bentuk organisasi. Dinas Pemerintahanan Desa Kabupaten Lumajang berdasarkan Peraturan Bupati Nomor 48 Tahun 2008 tentang Kedudukan, mempunyai tugas - tugas pokok: mengoordinasikan bahan penyusunan perumusan kebijakan, pedoman, petunjuk teknis pembinaan di bidang penyelenggaraan pemerintahan desa/kelurahan yang meliputi administrasi, kelembagaan, perangkat dan kekayaan Desa/kelurahan. Dinas Pemerintahan Desa Setda Kabupaten Lumajang. Keberhasilan suatu organisasi ditentukan oleh kepemimpinan yang dikembangkan pada organisasi itu dan kompetensi yang diberikan oleh anggota atau bawahannya untuk mencapai tujuan tersebut. Sejalan dengan pentingnya sumber daya manusia dalam organisasi, manusia merupakan unsur yang paling penting menentukan keberhasilan atau kegagalan suatu organisasi dalam menyelenggarakan berbagai kegiatannya dan dalam rangka pencapaian tujuan dan sasaran instansi/organisasi.

Setiap organisasi memiliki budaya yang berbeda. Masing - masing memiliki filosofi yang prinsip bisnisnya sendiri - sendiri. cara pemecahan permasalahan dan mengambil keputusan sendiri serta memiliki keyakinan, perilaku dan pola pemikiran, praktek bisnis, dan kepribadian sendiri. Dalam rangka mewujudkan budaya organisasi yang ditetapkan organisasi tersebut maka sangat diperlukan dukungan dan pertisipasi dari semua semua anggota yang ada dalam lingkup organisasi tersebut. Salah satu cara untuk membina dan meningkatkan gairah kerja karyawan adalah dengan jalan pemberian motivasi. Oleh karena itu, untuk mencapai tingkat efisiensi dan efektivitas kerja yang tinggi, suatu organisasi harus dapat merangsang pertumbuhan dan perkembangan karyawan, mengusahakan adanya keinginan untuk berprestasi serta mengetahui dan memenuhi kebutuhan karyawan. Pemberian motivasi ini berbeda antara karyawan satu dengan karyawan yang lain, hal ini disebabkan karena perbedaan motif, tujuan dan kebutuhan masing-masing karyawan.

Kepuasaan kerja (job satisfaction) karyawan merupakan sasaran penting dalam manajemen sumberdaya manusia, karena secara langsuang maupun tidak langsung akan mempengaruhi produktivitas kerja.
Penelitian ini mencoba menggambarkan kinerja karyawan dalam menjamin efktifitas dan efisiansi kerja semua karyawan, juga meningktkan rasa tanggung jawab social serta dituntut dituntut adanya partisipasi aktif dari seluruh karyawan.

\section{KAJIAN PUSTAKA}

\section{Kepemimpinan}

Menurut Robbins dalam Nawawi (2003) kepemimpinan adalah kemampuan mempengaruhi suatu kelompok kearah pencapain (tujuan). Menurut Sholehudin (2008) sifat sifat yang harus dimiliki oleh seorang pemimpin adalah Stamina, Ada sesuatu yang diperjuangkannya,Pemimpin harus Karakter , Pemimpin haruslah berpikiran bersih dan jujur, Simpati

\section{Budaya Organisasi}

Glaser (1987) Budaya Organisasi seringkali digambarkan dalam arti yang dimiliki bersama. Pola - pola dari kepercayaan, simbol - simbol, ritual - ritual, dan mitos mitos yang berkembang dari kewaktu dari waktu dan berfungsi - sebagai parekat yang menyangkut organisasi. Fungsi budaya dalam organisasi menurut McShane dan Glinof (2003) yaitu: bentuk kontrol sosial yang mempengaruhi keputusan dan perilaku karyawan, perekat sosial yang mengikat orang bersama - sama dan membuat mereka merasa bagian dari pengalaman organisasi.Budaya perusahaan membantu proses "pembuatan rasa (sense making) hal ini membantu karyawan memahami kegiatan organisasi dan karyawan dapat berkomunikasi lebih efisien.

\section{Motivasi}

Menurut M Manullang dan Marihot (2004) kata Motivasi berasal dari kata Motif yaitu tenaga pendorong yang mendorong manusia untuk bertindak atau suatu tenaga didalam diri manusi, yang menyebabkan manusia bertindak. Menurut Malayu S.P. Hasibuan (1999) pemberian motivasi kepada para bawahan atau karyawan oleh pemimpin atau manajer bertujuan untuk: Mendorong gairah dan kinerja karyawan karyawan; Meningkatkan moral dan kepuasan kerja karyawan; Mempertahankan loyalitas dan kestabilan karyawan di perusahaan; Meningkatkan kedisiplinan dan menurunkan absensi karyawan; Mengefektifkan pengadaan karyawan; Mencip-takan 
suasana dan hubungan kerja yang baik Meningkatkan kreativitas dan prestasi kerja karyawan; Meningkatkan tingkat kesejahteraan karyawan; Mempertinggi tanggung jawab karyawan terhadap tugasnya; Meningkatkan efisiensi penggunaan alat-alat dan bahan baku.

\section{Kepuasan Kerja}

Robbins (2003) mendefinisikan kepuasan kerja sebagai perbedaan antara banyaknya ganjaran yang diterima dalam suatu sikap pada suatu perilaku sehingga dalam hal ini diyakini bahwa karyawan yang puas akan lebih produktif dari pada karyawan yang tidak puas. Lebih lanjut pendapat Herzberg dalam Bruce (2003:113) mengemukakan dua faktor yang membedakan antara ketidak puasan dengan kepuasan kerja. Faktor yang menjadi sumber ketidak puasan kerja disebut Hygiene Factor's sedangkan faktor yang menjadi kepuasan kerja disebut Motivating.

1. Hygiene Factor's bersifat ekstrinsik yaitu sifat yang disebabkan karena hubungan pekerjaan dengan aspek lingkungan dengan aspek - aspek lingkungan pekerjaan, yang meliputi faktor - faktor sebagai berikut : (1)kebijakan perusahaan dan aministrasi,
(2) supervise, (3) hubungan dengan supervisor, (4) hubungan dengan rekan sekerja, (5) hubungan dengan bawahan, (6) gaji, (7) keamanan kerja, (8) kehidupan pribadi, (9) kondisi kerja, dan (10) status.

2. Motivating Factor's bersifat instrinsic yaitu selalu dihubungkan dengan isi dan jenis pekerjaan yang meliputi faktor - faktor sebagai berikut : (1) pencapain prestasi, (2) penghargaan, (3)kemajuan, (4) pekerjaan itu sendiri, (5) kemungkinan untuk mengembangkan karir, dan (6) tanggung jawab.

\section{Kinerja Karyawan}

Menurut Mangkunegara (2001) kinerja dapat didefinisikan sebagai hasil kerja secara kualitas dan kuantitas yang dapat dicapai oleh seorang pegawai dalam melaksanakan tugas sesuai dengan tanggung jawab yang diberikan kepadanya. instansi tempatnya bekerja. Bernandin (2007) mengemukakan enam kriteria primer yang dapat digunakan untuk mengukur pretasi kerja karyawan (kinerja) yaitu:

Quality, Quantity, Timelines Cost effectiveness, Need for supervision, Interpersonal impact

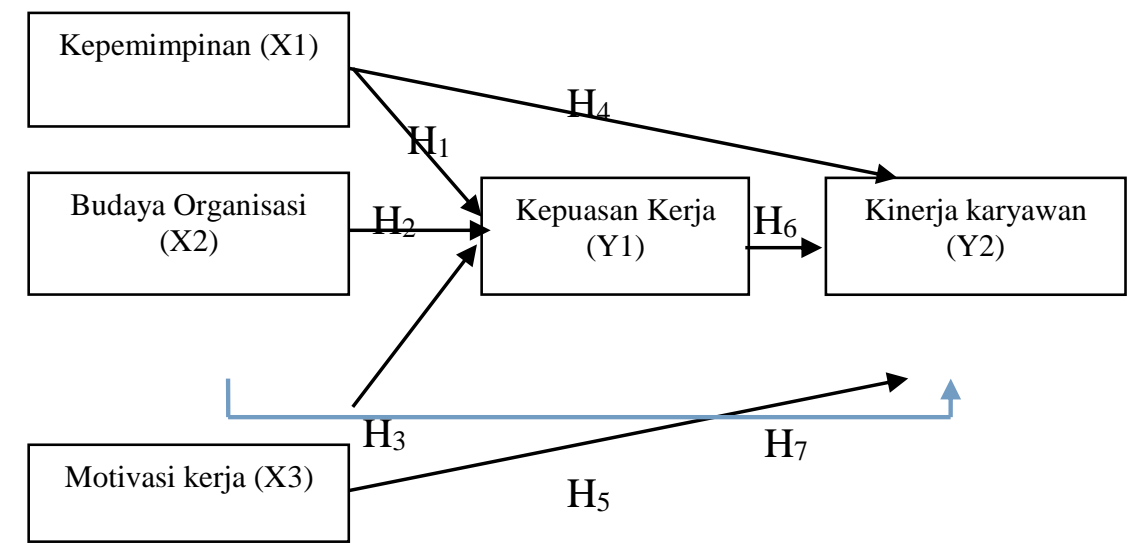

\section{Gambar 1 Kerangka Konseptual Penelitian}

\section{Hipotesis}

H1: Kepemimpinan berpengaruh seterhadap kepuasan kerja pada Dinas Pemerintahan Desa (PEMDES) Kabupaten Lumajang

$\mathrm{H} 2$ : Budaya organisasi berpengaruh terhadap kepuasan kerja pada Dinas Pemerintahan Desa (PEMDES) Kabupaten Lumajang
H3: Motivasi berpengaruh terhadap kepuasan kerja pada Dinas Pemerintahan Desa (PEMDES) Lumajang

H4: Kepemimpinan berpengaruh terhadap kinerja karyawan pada Dinas Pemerintahan Desa (PEMDES) Kabupaten Lumajang

H5: Budaya organisasi berpengaruh terhadap kinerja karyawan pada Dinas 
Pemerintahan Desa (PEMDES)

Kabupaten Lumajang

H6: Motivasi berpengaruh terhadap kinerja karyawan pada Dinas Pemerintahan Desa (PEMDES) Kabupaten Lumajang

H7: Kepuasan kerja berpengaruh pada kinerja karyawan pada Dinas Pemerintahan Desa (PEMDES) Kabupaten Lumajang

H8: Kepemimpinan mempunyai pengaruh tidak langsung terhadap kinerja karyawan melalui kepuasaan kerja pada Dinas Pemerintahan Desa (PEMDES) Kabupaten Lumajang

H9: Budaya organisasi mempunyai pengaruh tidak langsung terhadap kinerja karyawan melalui kepuasaan kerja pada Dinas Pemerintahan Desa (PEMDES) Kabupaten Lumajang

H10: Motivasi mempunyai pengaruh tidak langsung terhadap kinerja karyawan melalui kepuasaan kerja pada Dinas Pemerintahan Desa (PEMDES) Kabupaten Lumajang.

\section{Definisi Operasional dan Pengukuran Variabel}

\section{a. Kepemimpinan (X1)}

1. Peran Pemimpin: Kesempatan menyampaikan pendapat, Pemberian pengarahan dalam menjalankan tugas, Pemimpin memberi Pendelegasian wewenang, Pengendalian tugas

2. Pengikut : rasa hormat, rasa kagum serta, ketaatan, karyawan menerima pendelegasian wewenang

3. Mempunyai Situasi Organisasi: Tingkat kerja sama bawahan, Tingkat penyelisian konflik, Rasa percaya diri bawahan Menambah keterampilan bawahan

b. Budaya organisasi (X2)

1. Inovasi dan pengambilan risiko (Innovation and risk taking),

2. Orientasi hasil (outcome orientation),

3. Orientasi pada manusia (people orientation), Orientasi Tim (team orientation)

c. Motivasi (X3)

1. Upah : Besarnya upah, Sistem penggajian / pengupaha, Pemberian Insentif, Dasar pemberian Insentif, Jenis insentif yang diberikan

2. Kondisi fisik Tempat Kerja : Kondisi lingkungan kerja, Kondisi penerangan, Adanya sirkulasi udara, Peralatan kerja yang memadai, Ketenangan lingkungan kerja

3. Keamanan meliputi: Sarana yang disediakan sudah memandai, Sifat pekerjaan yang dihadapi sesuai dengan ketentuan yang berlaku, Banyaknya pekerjaan yang hadapi telah sesuai ketentuan yang berlaku, Ketenangan tempat kerja sudah memadai, Rasa aman dalam perlindungan kerja telah terpenuhi

d. Kepuasan kerja (Y1) : Pekerjaan itu sendiri, Gaji, Rekan kerja, tingkat dimana rekan kerja

e. Kinerja Karyawan (Y2) : Quality, Quantity, Timelines, Effectiveness, Need for supervision, Interpersonal impact.

\section{METODE \\ Populasi Penelitian}

Menurut Arikunto (2002), populasi adalah keseluruhan subyek penelitian. A population is a set (or collection) of all elements possesing one or more attributes of interest.Selanjutnya dalam penelitian ini, karena jumlah populasi tidak begitu besar yaitu 80 orang karyawan, maka penelitian ini menggunakan metode sensus. Sampel yang diambil adalah semua anggota populasi yang ada. Kuesioner diberikan kepada seluruh karyawan Dinas Pemerintahan Desa (PEMDES) Kabupeten Lumajang.

\section{Metode Pengukuran}

Menurut Santoso (2002:269), skala Likert digunakan untuk mengukur sikap pendapat dan persepsi seseorang atau kelompok tentang fenomena sosial.

Dalam hal ini, variabel bebas / independent adalah Pengaruh kepemimpinan Dan Motivasi Kerja maupun variabel terikat/ dependent adalah Kepuasan kerja, menggunakan skala 5 tingkat, yang terdiri dari : Sangat setuju (SS), Setuju (S), Ragu - ragu (RR), Tidak Setuju (TS)

\section{Pengumpulan Data \\ Sumber Data}

1. Data primer Dalam penelitian ini data primer diperoleh langsung dari lokasi penelitian yaitu melalui wawancara secara langsung dan yang tidak langsung melalui penyebaran kuesioner.

2. Data sekunder Dalam penelitian ini data 
sekunder diperoleh dari organisasi baik berupa jumlah karyawan, sejarah organisasi dan struktumya maupun literatur pendukung.

\section{Analisis Data}

Teknik analisis data yang digunakan dalam penelitian ini yaitu analisis jalur (path analysis). Analisis jalur (path analysis) digunakan untuk menguji sebab akibat berdasarkan pada pengetahuan

\section{Pengujian Hipotesis}

Uji hipotesis yang digunakan dalam penelitian ini baik untuk direct effect maupun indirect effect menggunakan uji t. Dasar pengambilan keputusannya berdasarkan kriteria dari uji t koefisien path, yaitu:

- Jika nilai t hitung > t tabel maka terdapat pengaruh signifikan pada jalur yang dipilih $\left(\mathrm{H}_{0}\right.$ ditolak, $\mathrm{H}_{\mathrm{a}}$ diterima $)$, begitu pula sebaliknya, atau

- Jika nilai Sig.(p-value) $<\alpha$ maka maka terdapat pengaruh signifikan pada jalur yang dipilih $\left(\mathrm{H}_{0}\right.$ ditolak, $\mathrm{H}_{\mathrm{a}}$ diterima), begitu pula sebaliknya.

\section{HASIL PENELITIAN}

\section{Uji Validitas}

Hasil uji validitas pada pengujian ini untuk masing-masing variabel yaitu kepemimpinan, budaya organisasi, motivasi kerja, kepuasan kerja dan kinerja adalah valid, karena terbukti bahwa nilai koefisien lebih besar dari nilai kritik atau tabel pada tingkat signifikan 5\%.

\section{Uji Reliabilitas}

Hasil uji reliabilitas seluruh variabel yang digunakan dalam penelitian ini adalah reliabel, hal tersebut dikarenakan koefisien Cronbach's Alpha diatas 0,6. Berdasarkan hasil analisis dapat disimpulkan bahwa semua instrumen dalam penelitian ini meskipun dilakukan pengujian secara berulang-ulang dapat menghasilkan hasil yang sama sehingga dapat digunakan untuk menjelaskan pengaruh kepemimpinan, budaya organisasi, motivasi terhadap kepuasan kerja dan kinerja karyawan pada Dinas Pemerintahanan Desa Kabupaten Lumajang (PEMDES).
Hasil Analisis Data

Pengaruh Kepemimpinan Terhadap Kepuasan Kerja Pada Dinas Pemerintahan Desa (PEMDES) Kabupaten Lumajang

$$
\mathrm{Y}_{1}=19,603+0,328 \mathrm{X}+\mathrm{e}
$$

a. Nilai konstanta sebesar 19,603 yang menunjukkan nilai kepuasan kerja apabila kepemimpinan sama dengan nol.

b. Variabel kepemimpinan memiliki pengaruh positif terhadap kepuasan kerja dengan nilai koefisien $=0,328$, artinya apabila kepemimpinan 1 semakin baik maka kepuasan kerja pegawai akan semakin meningkat.

\section{Pengaruh budaya organisasi terhadap} kepuasan kerja pada Dinas Pemerintahan Desa (PEMDES) Kabupaten Lumajang

$$
\mathrm{Y}_{1}=22,607+0,451 \mathrm{X}+\mathrm{e}
$$

a. Nilai konstanta sebesar 22,607 yang menunjukkan nilai kepuasan kerja apabila budaya organisasi sama dengan nol.

b. Variabel budaya organisasi memiliki pengaruh positif terhadap kepuasan kerja dengan nilai koefisien $=0,451$, artinya apabila budaya organisasi semakin baik maka kepuasan kerja pegawai akan semakin meningkat.

Pengaruh motivasi terhadap kepuasan kerja pada Dinas Pemerintahan Desa (PEMDES) Lumajang

$$
\mathrm{Y}_{1}=20,691+0,340 \mathrm{X}+\mathrm{e}
$$

a. Nilai konstanta sebesar 20,691 yang menunjukkan nilai kepuasan kerja apabila motivasi kerjasama dengan nol.

b. Variabel motivasi kerja memiliki pengaruh positif terhadap kepuasan kerja dengan nilai koefisien $=0,340$, artinya apabila motivasi kerja semakin tinggi maka kepuasan kerja pegawai akan semakin meningkat.

Pengaruh kepemimpinan terhadap kinerja karyawan pada Dinas Pemerintahan Desa (PEMDES) Kabupaten Lumajang

$$
\mathrm{Y}_{1}=0,757+0,613 \mathrm{X}+\mathrm{e}
$$

a. Nilai konstanta sebesar 0,757 yang menunjukkan nilai kinerja karyawan apabila kepemimpinan sama dengan nol.

b. Variabel kepemimpinan memiliki pengaruh positif terhadap kinerja karyawan dengan nilai koefisien $=0,613$, artinya apabila 
kepemimpinan semakin baik maka kinerja pegawai akan semakin meningkat.

Pengaruh budaya organisasi terhadap kinerja karyawan pada Dinas Pemerintahan Desa (PEMDES) Kabupaten Lumajang

$$
\mathrm{Y}_{1}=8,407+0,765 \mathrm{X}+\mathrm{e}
$$

a. Nilai konstanta sebesar 8,407 yang menunjukkan nilai kinerja karyawan apabila budaya organisasi sama dengan nol.

b. Variabel budaya organisasi memiliki pengaruh positif terhadap kinerja karyawan dengan nilai koefisien $=0,765$, artinya apabila budaya organsiasi semakin baik maka kinerja pegawai akan semakin meningkat.

Pengaruh motivasi terhadap kinerja karyawan pada Dinas Pemerintahan Desa (PEMDES) Kabupaten Lumajang

$$
\mathrm{Y}_{1}=4,562+0,592 \mathrm{X}+\mathrm{e}
$$

a. Nilai konstanta sebesar 4,562 yang menunjukkan nilai kinerja karyawan apabila motivasi kerja sama dengan nol.

b. Variabel motivasi kerja memiliki pengaruh positif terhadap kinerja karyawan dengan nilai koefisien $=0,592$, artinya apabila motivasi kerja semakin tinggi maka kinerja pegawai akan semakin meningkat.

Pengaruh kepuasan kerja terhadap kinerja karayawan pada Dinas Pemerintahan Desa (PEMDES) Kabupaten Lumajang

a. Nilai konstanta sebesar -10,694 yang menunjukkan nilai kinerja karyawan apabila kepuasan kerja sama dengan nol.

b. Variabel kepuasan kerja memiliki pengaruh positif terhadap kinerja karyawan dengan nilai koefisien $=0,592$, artinya apabila motivasi kerja semakin tinggi maka kinerja pegawai akan semakin meningkat

\section{PEMBAHASAN}

Pengaruh kepemimpinan terhadap kepuasan kerja pada Dinas Pemerintahan Desa (PEMDES) Kabupaten Lumajang

Hasil analisis menunjukkan bahwa terdapat pengaruh yang signifikan antara kepemimpinan terhadap kepuasan kerja para pegawai di Dinas Pemerintahan Desa (PEMDES) Kabupaten Lumajang. Melalui kepemimpinan yang tepat maka dengan sendirinya upaya perusahaan untuk memberikan jaminan kepuasan dalam bekerja para karyawan dapat terwujud. Kepemimpinan dapat memotivasi para karyawan untuk bekerja secara maksimal diperusahaan dan pada akhirnya meningkatkan kepuasan dalam bekerja diperusahaan.

Pengaruh budaya organisasi terhadap kepuasan kerja pada Dinas Pemerintahan Desa (PEMDES) Kabupaten Lumajang

Hasil analisis menunjukkan bahwa terdapat pengaruh yang signifikan antara budaya organisasi terhadap kepuasan kerja para pegawai di Dinas Pemerintahan Desa (PEMDES), bahwa budaya organisasi yang kuat akan memicu karyawan untuk berfikir, berperilaku, dan bersikap sesuai dengan nilainilai organisasi.

Pengaruh motivasi terhadap kepuasan kerja pada Dinas Pemerintahan Desa (PEMDES) Lumajang

Berdasarkan hasil analisis menunjukkan bahwa terdapat pengaruh yang signifikan antara motivasi terhadap kepuasan kerja para pegawai di Dinas Pemerintahan Desa (PEMDES) Kabupaten Lumajang. Bahwa, motivasi kerja seseorang karyawan sangat berpengaruh terhadap kepuasan kerja karyawan yang dapat dicapai pada pekerjaannya. Pemberian motivasi secara individu kepada karyawan akan berjalan lebih cepat sehingga karyawan dapat bekerja secara maksimal di perusahaan.

Pengaruh kepemimpinan terhadap kinerja karyawan pada Dinas Pemerintahan Desa (PEMDES) Kabupaten Lumajang

Hasil analisis menunjukkan bahwa terdapat pengaruh yang signifikan antara kepemimpinan terhadap kinerja para pegawai di Dinas Pemerintahan Desa (PEMDES) Kabupaten Lumajang. Kepemimpinan (leadership) dapat dikatakan sebagai cara dari seorang pemimpin (leader) dalam mengarahkan, mendorong dan mengatur seluruh unsur-unsur di dalam kelompok atau organisasinya untuk mencapai suatu tujuan organisasi yang diinginkan sehingga menghasilkan kinerja pegawai yang maksimal.

Pengaruh budaya terhadap kinerja karyawan pada Dinas Pemerintahan Desa (PEMDES) Kabupaten Lumajang

Berdasarkan hasil analisis menunjukkan bahwa terdapat pengaruh atara budaya 
organisasi terhadap kinerja karyawan para pegawai di Dinas Pemerintahan Desa (PEMDES) Kabupaten Lumajang. Budaya organisasi dapat membantu kinerja karyawan, karena menciptkan motivasi yang besar bagi pegawai untuk memberikan kemampuan terbaiknya dalam memanfaatkan kesempatan yang diberikan oleh organisasinya.

Pengaruh motivasi terhadap kinerja karyawan pada Dinas Pemerintahan Desa (PEMDES) Kabupaten Lumajang

Hasil analisis menunjukkan bahwa terdapat pengaruh yang signifikan antara motivasi terhadap kinerja para pegawai di Dinas Pemerintahan Desa (PEMDES) Kabupaten Lumajang. Pengaruh motivasi harus dapat menggerakkan kemauan kerja karyawan supaya bekerja labih baik dan benar guna mencapai kinerja. Dengan kinerja yang tinggi dan hasil yang didapatkan sesuai dengan yang diinginkan perusahaan akan menyebabkan karyawan lebih semangat untuk bekerja tersebut.

Kepuasan kerja berpengaruh pada kinerja karayawan pada Dinas Pemerintahan Desa (PEMDES) Kabupaten Lumajang

Hasil analisis menunjukkan bahwa terdapat pengaruh Kepuasan kerja berpengaruh pada kinerja karayawan pada Dinas Pemerintahan Desa (PEMDES) Kabupaten Lumajang. Dengan demikian dapat dikatakan bahwa dengan adanya perubahan kepuasan pegawai denga sendirinya akan memberikan dampak positif terhadap pencapaian kinerja. Dengan kata lain semakin puas para pegawai bekerja di instansi maka upaya untuk memaksimalkan kemampuan atau potensi dapat terwujud secara maksimal.

Kepemimpinan mempunyai pengaruh tidak langsung terhadap kinerja karyawan melalui kepuasaan kerja pada Dinas Pemerintahan Desa (PEMDES) Kabupaten Lumajang

Kepemimpinan mempunyai pengaruh tidak langsung terhadap kinerja karyawan melalui kepuasaan kerja pada Dinas Pemerintahan Desa (PEMDES) Kabupaten Lumajang. Adanya pengaruh secara tidak langsung menunjukkan bahwa terdapat keterkaitan antara ketiga variabel yang meliputi kepemimpinan, kinerja karyawan dan kepuasan kerja karyawan. Adanya perubahan ketiga variabel tersebut dapat memberikan dampak atau pengaruh terhadap ketiga variabel terkait upaya instansi untuk meningkatkan kepuasan dan kinerja para karyawan dalam bekerja diinstansi.

Budaya organisasi mempunyai pengaruh tidak langsung terhadap kinerja karyawan melalui kepuasaan kerja pada Dinas Pemerintahan Desa (PEMDES) Kabupaten Lumajang

Berdasarkan hasil analisis dapat diketahui bahwa budaya organisasi mempunyai pengaruh tidak langsung terhadap kinerja karyawan melalui kepuasaan kerja pada Dinas Pemerintahan Desa (PEMDES) Kabupaten Lumajang. Hasil tersebut menunjukkan bahwa terdapat keterkaitan antara budaya organisasi, kinerja dan kepuasan kerja karyawan. Semakin baiknya kondisi budaya organisasi pada instansi maka upaya peningkatan perbaikan kinerja dan kepuasan para pegawai dalam bekerja dapat terwujud secara maksimal.

Dari hasil analisis menunjukkan bahwa dengan semakin baikknya budaya organisasi pada perusahaan maka dengan sendirinya akan memberikan dukungan dalam upaya untuk meningkatkan kepuasan karyawan. Kondisi ini menjadikan para karyawan memiliki keinginan untuk bekerja lebih baik sesuai dengan harapan instansi.

Motivasi mempunyai pengaruh tidak
langsung terhadap kinerja karyawan
melalui kepuasaan kerja pada Dinas
Pemerintahan Desa (PEMDES) Kabupaten
Lumajang
$\quad$ Hasil analisis dapat diketahui bahwa motivasi mempunyai pengaruh tidak langsung terhadap kinerja karyawan melalui kepuasaan kerja pada Dinas Pemerintahan Desa (PEMDES) Kabupaten Lumajang. Dengan demikian adanya perubahan atas motivasi kerja para pegawai akan memberikan dampak positif terhadap upaya menciptakan atau meningkatkan kepuasan dan kinerja pegawai.

Motivasi pada dasarnya merupakan dorongan para karyawan untuk bekerja secara maksimal di instansi. Apabila kondisi ini terwujud maka dengan sendirinya dapat menciptaka dalam bekerja dan selajutnya mampu mendukung upaya instansi untuk memaksimalkan potensi karyawan dan pada akhirnya dapat meningkatkan kinerja para karyawan dalam bekerja diinstansi. 


\section{Implikasi Hasil Penelitian}

Adanya pengaruh signifikan antara kepemimpinan terhadap kepuasan kerja para pegawai di Dinas Pemerintahan Desa (PEMDES) Kabupaten Lumajang dapat memberikan gambaran mengenai sejauh mana upaya instansi dalam memberikan jaminan kepuasan kerja pegawai. Kondisi ini menjadi jaminan bahwa upaya instansi memberikan jaminan kepuasan akan memberikan suatu bentuk dukungan kepemimpinan yang tepat sesuai dengan kondisi perusahaan dan karyawan. Hasil analisis menunjukkan bahwa terdapat pengaruh yang signifikan antara budaya organisasi terhadap kepuasan kerja para pegawai di Dinas Pemerintahan Desa (PEMDES) Kabupaten Lumajang. Dari hasil tersebut maka dapat dikatakan bahwa pihak manajemen harus selalu berupaya untuk menciptakan kepuasan melalui kondisi budaya organisasi yang bear-benar mendukung dan sesuai dengan karakter yang terdapat diperusahaan.

Hasil analisis menunjukkan bahwa terdapat pengaruh yang signifikan antara motivasi terhadap kepuasan kerja para pegawai di Dinas Pemerintahan Desa (PEMDES) Kabupaten Lumajang. Dalam usaha untuk meningkatkan motivasi kerja para karyawan sehingga tenaga kerja yang terdapat diperusahaan dapat secara efektif mendukung tujuan yang telah ditetapkan oleh perusahaan. Pada sisi yang lain penggunaan tenaga kerja yang efektif merupakan kunci keberhasilan perusahaan, untuk itu dibutuhkan kebijakan dalam menggunakan tenaga kerja agar mau bekerja lebih produktif sesuai dengan rencana yang telah ditetapkan. Usaha nyata yang dapat dilakukan yaitu dengan memberikan motivasi atau dorongan kepada karyawan.

Adanya pengaruh yang signifikan antara kepemimpinan terhadap kinerja para pegawai di Dinas Pemerintahan Desa (PEMDES) Kabupaten Lumajang. Kepemimpinan dalam suatu perusahaan merupakan suatu faktor yang menentukan berhasil atau tidaknya organisasi dalam mencapai tujuan-tujuannya. Faktor ini berfungsi sebagai pendorong dalam rangka untuk peningkatan kinerja para karyawan dalam rangka mewujudkan tujuan organisasi. Kemampuan seorang pimpinan untuk memberikan dukungan terkait dalam upaya peningkatan kinerja karyawan sangat diperlukan. Pemimpin dapat pula berperan sebagai pendorong yang harus mempunyai kemampuan memahami orang lain, bisa menghargai anak buahnya dan punya integritas yang tinggi. Kenyataan ini memberikan bukti bahwa adanya keterkaitan antara gaya kepemimpinan dengan pencapaian kinerja karyawan. Kenyataan tersebut menjadikan kepemimpinan yang tepat akan mendukung upaya untuk menciptakan kinerja karyawan yang lebih bagus. Pasa sisi yang lain upaya instansi untuk menciptakan budaya organisasi yang tepat akan memberikan dukungan atau jaminan bahwa aktivitas para karyawan dapat berjalan sesuai dengan ketentuan yang telah ditetapkan.

\section{KESIMPULAN DAN SARAN}

\section{Kesimpulan}

1. Kepemimpinan yang di terapkan pada karyawan mampu memberikan kepuasan kerja karyawaan Dinas Pemerintahan Desa KabupatenLumajang (PEMDES). Melalui sikap kepercayaan diri yang di tampilkan pemimpin bahwa dia memiliki kemampuan untuk mencapai tujuan yang di harapkan perusahaan, pemberian motivasi kepada bawahannya, rasa ingin tahu yang di miliki pemimpin yang senantiasa untuk terus menerus belajar. Integritas pemimpin yang diterapkan dalam keseharian sebagai pemberi contoh dari penerjemahan kata kata yang di sampaikan, Dan mendorong Bawahan untuk bergerak maju dan meyakinkan bawahan nya bahwa dia mampu memimpin,serta kecerdasan emosional yang tinggi dalam memantau emosinya dan emosi karyawan dalam memandu pikiran dan tindakan.

2. Budaya organisasi di Dinas Pemerintahan Desa Kabupaten Lumajang (PEMDES)

Dapat mendorong peningkatan kepuasan kerja. Adanya penerapan yang tinggi oleh karyawan berupa sikap budaya perhatian yang rinci berupa sikap budaya perhatian yang Rinci dimana karyawan bekerja dengan cermat dan yang Rinci serta penuh daya analisa.Dalam rangka meningkatkan kontribusi pada organisasi (Instansi) suda ada mulai dorongan dari Instansi untuk melakukan inovasi-inovasi dalam mengembangkan usaha. Serta adanya perhatian dari Instansi atas keputusan yang di ambil yang Senantisa memperhatikan efek hasil pada karyawan sehingga tercipta 
kepuasan kerja bagi karyawan dalam bekerja.

3. Budaya organiasasi belum mampu meningkatkan kinerja karyawan Dinas Pemerintahan Desa Kabupaten Lumajang (PEMDES), budaya akan memberikan pengaruh pada peningkatan kinerja, apabila pemimpin / Organisasi melakukan peningkatan kepuasaan kerjat erlebih dahulu, karena kepuasan kerja menjadi variable intervening dan memberikan pengaruh yang lebih besar kepada kinerja.

4. Kepemimpinan belum mampu meningkatkan kinerja karyawan Dinas Pemerintahan Desa Kabupaten Lumajang (PEMDES). Kepemimpinan hendaknya memberikan pemenuhan kepuaasaan kerja karyawan terlebih dahulu, karena dampak peningkatan kinerja melalui kepuasaan kerja sebagai sebagai variable antara lebih besar memberikan pengaruh daripada peningkatan kinerja melalui kepemimpinan langsung.

5. Kepuasaan kerja yang dirasakan karyawan mampu meningkatkan kinerja Dinas Pemerintahan Desa Kabupaten Lumajang (PEMDES). Terutama kepuasaankerja yang dirasakan seperti pekerjaan itu sendiri, gaji yang diterima dan kesempatan promosi bagi karyawan berdampak terhadap kinerja.

\section{Saran}

1. Untuk mencapai peranan budaya organisasi yang maksimal, diharapkan dapat ditingkatkan jiwa korsa diantara sesama karyawan Perum sesame nilai - nilai dasar Dinas Pemerintahan Desa Kabupaten Lumajang (PEMDES ) yaitu teamwork dan penerapan budaya kompetitif untuk memberikan konstribusi yang lebih untuk kemajuan instansi.Dalam melakukan inovasi - inovasi yang dituntut instansi untuk pengembangan usaha hendaknya instansi juga harus menghargai pengambilan resiko yang dilakukanolehkaryawan (selagi yang dilakukan karyawan bukan untuk kepentingan pribadi dan kelompok) dalam memberikan konstribusi kepada instansi sebagai proses pembelajaran kemajuan bagi diri dan untuk instansi kedepan, dengan tetap mengacu/memperhatikan pada prosedur yang berlaku sehingga sehingga diharapkan hasil yang diperoleh dapat lebih baik dan maksimal.

2. Pemimpin diharapkan lebih mampu untuk menangani, mempengaruhi, membimbing dan menyarankan bawahanya agar mereka mau berbuat sesuatu demi tercapainya tujuan bersama.

3. Pemimpin diharapkan dapat mengetahui motivasi apa yang tepat untuk karyawannya, sehingga kinerja karyawan dalam melaksanakan tugas pekerjaannya akan meningkat.

4. Dalam meningkatkan kinerja, efektifitas penggunaan sumber daya organisasi untuk mendapatkan hasil yang maksimal tetap harus ditanamkan kepada para pegawai dengan tidak melupakan sikap mawas diri karyawan agar mampu bekerja dengan baik tanpa harus ada pengawasan sehingga mampu mencegah tindakan yang tidak diinginkan.

\section{DAFTAR PUSTAKA}

Abdullaoh. 2006. Pengaruh Budaya Organisasi Locus Of Control Dan Kepuasan Kerja Terhadap Kinerja Karyawan Pada Kantor Pelayanan Pajak Semarang Barat. Universitas Brawijaya Malang.

Agus Sabari, 1997, Pengantar Manajemen, Penerbit UPP AMP YKPN, Yogyakarta.

Anoraga, Panji. 1992. Psikologi Kepemimpinan. Penerbit Gunung Agung. Jakarta.

Arikunto, Suharsimi, 2002, Prosedur Penelitian , Edisi Revisi V, Pt Rineka Cipta, Jakarta.

Brahmasari ,Ida Ayu, Suprayetno Agus.2008. Pengaruh Motivasi Kerja, Kepemimpinan Dan Budaya Organisasi Terhadap Kepuasaan Kerja Karyawan Serta Dampaknya Terhadap Kinerja Karyawan (Studi Kasus pada PT Pei Hai Internasional Wiratama Indonesia).Jurnal Manajemen dan kewirausahaan, Vol.10, no 2, september 2008, 124-135. Pasca sarjana Univ. 17 Agustus, Surabaya.

Bruce, Anne, 2003, How to Motivate Every Employee, 24 Point penting Seputar peningkatan Produktivitas di tempat Kerja. Jakarta: Buana Ilmu Komputer.

Cooper,D.R C. W Emory.2000. Metode Penelitian Bisnis Jilid 1 Edisi Ke 6. Jakarta : Erlangga.

Dajan, Anton, 1986, Pengantar Metode Statistik Jilid II, LP3ES, Jakarta.

David, Keith and, John W. Newstrom. 1985. Human Behavior At Work : 
Organizational Behavior, Seventh Edition, McGraw Hill Inc., Agus Dharma (Penerjemah), 1985. Perilaku Dalam Organisasi, Erlangga, Jakarta.

Dessler, Gary, 1992, Manajemen Personalia, Teknik dan Konsep Modern, Diterjemahkan oleh : Agus Dharma, Erlangga, Edisi Ketiga, Jakarta.

Winardi, 2000. Kepemimpinan Dalam Organisasi. Cetakan Kedua. Penerbit PT. Rineka Cipta. Jakarta.

Indriyo Gitosudarmo, 1997. Perilaku Keorganisasian. Edisi Pertama. Penerbit BPFE. Yogyakarta.

Durbin Andrew J, 2005. Leadership Terjemahan. Edisi Kedua, Prenad Media, Jakarta.

Glaser, Susan R ; Zamanaou Sonia And Hacker Kennet, 1987, Measuring and Interpreting Organizational Culture. Management Comunication Qualety, Vol 1 no 2 pp 173 -178 .

Gibson, James L, Jhon M.Ivancevich.and James H.Donnelly Jr.1999. Organization : Behaviour, Structure, Proceses. 8 th ed.Boston: Richad D.Irwin

Handari, Nawawi.2003. Kepemimpinan Mengefektifkan Organisasi. Cetakan Pertama. Penerbit Gajah Mada University Press. Yogyakarta.

Handoko, T. Hani. 2001. Manajemen Personalia dan Sumber Daya Manusia. BPFE. Yogyakarta.

Harbani, Pasalong. 2008. Kepemimpinan Birokrasi. Penerbit Alfa Beta. Bandung.

Hariandja, M, 2005, Manajemen Sumber Daya Manusia, Pengadaan, Pengembangan, Pengkompensasian, dan Peningkatan Produktivitas Pegawai, PT. Grasindo, Cetakan Ketiga, Jakarta.

Hasibuan, M, 1996, Organisasi dan motivasi, Dasar Peningkatan Produktivitas, Bumi Aksara, Cetakan Pertama, Jakarta.

Hasibuan, M, 1999, Organisasi dan motivasi, Dasar Peningkatan Produktivitas, Bumi Aksara, Cetakan Revisi, Jakarta.

Heidjrachman dan Husnan, Suad, 1997, Manajemen Personalia, BPFE, Yogyakarta.

Koemono, HT. 2005. Pengaruh budaya organisasi terhadap motivasi dan kepuasan kerja serta Kinerja karyawan pada sub sector industri pengolahan kayu menengah di JawaTimur. Jurnal Manajemen \& kewirausahaan .Vol.7 No. 2 September 2005, p.171-188.

Klein, j , Takade- Tinker B.2009. The Impact Of Leadership On Cominity College Faculty Bjob Satisfaction. Academic Leadership Journal . Vol 7 Issue 2.

Kreitner, Robert. Kinicki Angelo. 2000. Organizational Behaviour, 5th ed, The McGraw-Hill Companies Inc Erly Suandy (Penerjemah) 2005. Perilaku Organisasi, Edisi 5 . Salemba Empat, Jakarta.

Kreitner, Robert. Kinicki Angelo. 2003. Perilaku Oganisasi. Alih Bahasa Erly Suandy. Penerbit Salemba Empat. Jakarta.

Kreitner, Robert. Kinicki Angelo. 2005. Organizational Behaviour, 5th ed, The McGraw-Hill Companies Inc Erly Suandy (Penterjemah) 2005. Perilaku Organisasi, Edisi 5 . Salemba Empat, Jakarta.

Luthans, F.2006. Perilaku organisasi, Edisi Sepuluh. Andi Yogyakarta.

Mamik, (2009).Pengaruh kepemimpinan, terhadap kinerja karyawan dan kepuasan kerja karyawan (Pada Industri Kertas di JawaTimur ). Universitas Brawijaya Malang.

Manahan P Tampubalon. 2004. Perilaku Organisasi. Edisi Pertama. Penerbit Ghalia Indonesia. Jakarta.

Mangkunegara Anwar Prabu. 2005. Manajemen Sumber Daya Manusia Perusahaan, Cetakan Keenam, PT. Remaja Rosdakary, Bandung.

Marihot, Manullang. 2004. Manajemen Personalia. Penerbi Gajah Mada University Press. Yogyakarta.

Mariam Rani.2009.Pengaruh Gaya Kepemimpinan Dan Budaya Organisasi Terhadap Kinerja Karyawan Melalui Kepuasan Kerja Sebagai Variabel Intervening Studi Pada Kantor Pusat Pt. Asuransi Jasa Indonesia (Persero). Universitas Brawijaya Malang.

Masri Singarimbun,dan Sofian Effeandi.1995. Metode Penelitian Survei. Jakarta: LP3ES.

McShane, SL., and Glinof. M.A 2003. Organizational Behavior : Emerging Realities for The Workplace Revolution. Second Edition (International Edition). McGraw-Hill International Edition.

Moenir. 1983. Manajemen Sumber Daya Manusia. PT. Rajawali, Surabaya.

Munandar, A. S. 2003. Learning Organization dan Penerapannya Dalam Dunia Usaha. 
Makalah Seminar Industri Kolokium Di Makassar.

Nitisemoto, Alex, S. 1996. Manajemen Personalia : Manajemen Sumberdaya manusia, Jakarta : Ghalia Indonesia.

Ogbonna, E dan Harris LC. 2000. Leadhership Style, Organizational Culture And Performance : Emprical Evidence From UK Companies. International Journal Of Human resources management 11: 4 Agustus 2000. P 766 - 788 http://www.tandf.co.uk/journals.

Robbins, Stephen, 1996. Perilaku Organisasi: Konsep Kontroversi, Aplikasi jiliid I Dan II, Alih Bahasa Adyana Pujatmaka, PT. Prenhalindo, Jakarta.

Robbins, Stephen, P.1998. Organizational Behavior. : Concepts, Controversies Applications, Eight Editon, Prentice Hall, Inc Hadyana Pujaatmaka (Penterjemah). 2002. Perilaku Organisasi: Konsep Kontroversi, Aplikasi, PT Prenhalindo, Jakarta.

Robbins, Stephen P \& Marry Coulter, 2002. Management. Seventh Edition Prentice Hall, Inc T. Hermaya (penerjemah). 2004. Management. Pt Indeks Jakarta.

Robbins, Stephen P. 2003. Perilaku Organisasi. Jakarta. PT Indeks Kelompok Gramedi Human

Robbins, Stephen, P. Timothy A. Judge, 2008, Perilaku Organisasi: Jilid I dan II, Edisi ke 12. Penerbit Salemba Empat. Jakarta.

Rose, Rc, dkk. 2008. Organizational Culture and Performance : Improvement : Research and recommendations. Contemporary
Management Research. Vol 4 no. 1, March. P. 43 - 56.

Rongga, Kirk L. 2001. Human Resorces practices, Organizational Climate and Employee Satisfaction, Academy $O f$ Management Review, July, 619-644

Sugiyono. 2005. Metode penelitian Bisnis.Bandung. : Alfabeta

Santosa, Purbayu Budi dan Ashari, 2005, Analisis Statistik dengan Microsoft Excel dan SPSS, Penerbit Andi, Yogyakarta.

Sandbakken, DA. 2009. : Leadheship practices And Organizational Performance a Norwegian Study. to be Publishedin EDAMBA Journal.

Santoso, Singgih, 2002, Mengolah Data Statistik Secara Profesional SPSS Versi 10, PT. Elex Media Komputindo, Jakarta.

Sarwoto, 1996. Dasar - dasar organisasi dan Manajemen. Yogyakarta : Liberty.

Schein, Edgar H. 2002. Organization Culture And Leadhership, $2^{\text {nd }}$ Edition. Jossey- Bas Publisher. San Fransisco.

Schein, Edgar H. 2004. Organization Culture And Leadhership, $2^{\text {nd }}$ Edition. Jossey- Bas Publisher. San Fransisco.

Setiawan, Juli. 2001. Perilaku organisasi, Managemen Usahawan Indonesia, No 06/TH.XXX Juni 2001, Lembaga Management FE- UI.Jakarta.

Sholehuddin, M.pd. 2008. Kepemimpinan Pemuda Dalam Berbagai Perspektif. Cetakan Pertama. Penerbit PT. Intimedia Cipta Nusantara. Jakarta Timur.

Sugiyono.2001. Metode Penelitian Bisnis. Bandung: Alfa Beta. 